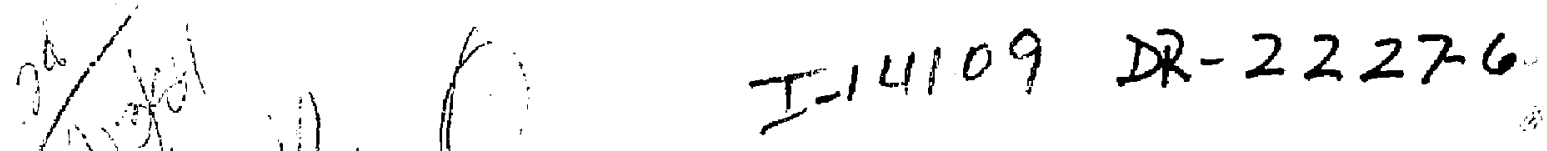

UCID- 20042

Monte Carlo Calculations of 14-MeV Neutron

Multiplication in Thick Bery]lium Assemblies

and Comparison with Experimental Results

James C. Doyle, Jr.

J. D. Lee

February 29, 1984

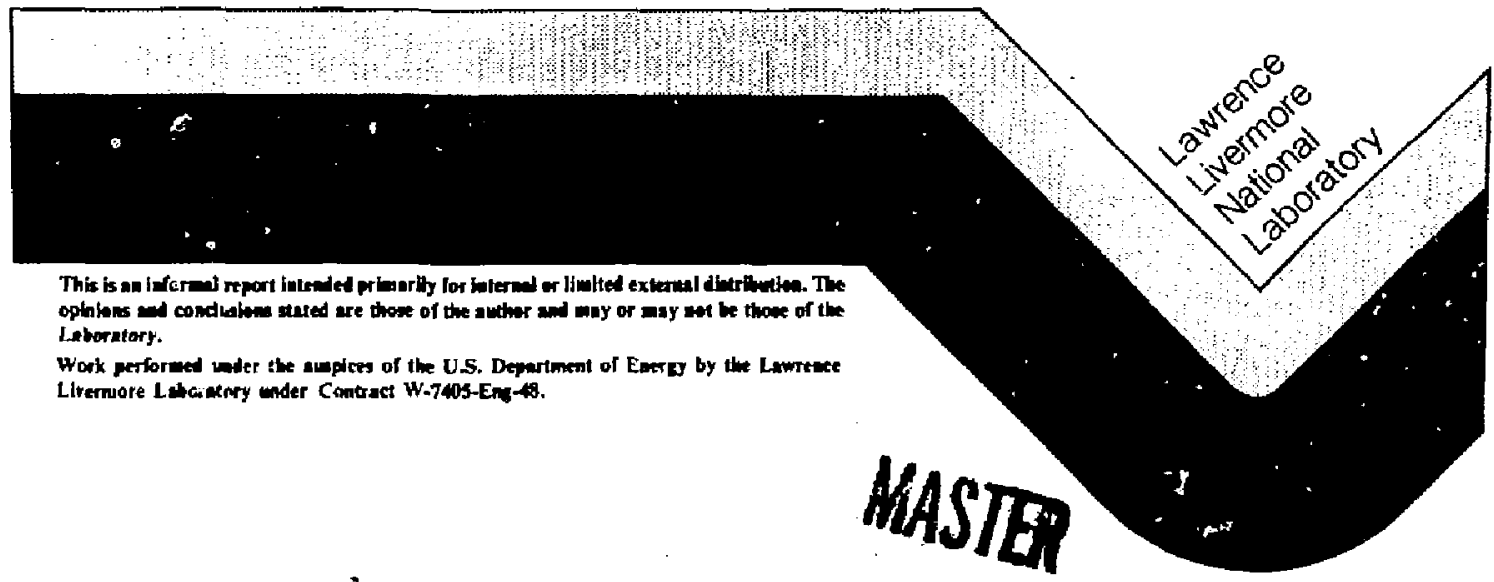

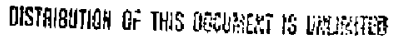




\title{
MONTE CARLO CALCULATIONS OF 14-MEV NEUTRON MULTIPLICATION IN THICK BERYLLIUM ASSEMBLIES AND COMPARISON WITH EXPERIMENTAL RESULTS
}

James $C$. Doyle, Jr. ${ }^{\dagger}$ and $\}$. D. Lee

Lawrence Livermore National Laboratory, University of Californi..

P. 0. Box $5511, L-644$

Livermore, CA 94550

UCID- $-200 \mathrm{H}^{2}$

DEG4 003523

\section{DISCLAIMER}

\begin{abstract}
DISCLAIthe This report was prepared as an acoount of work sponsored by an agency of the Unild St their This repot was prepar the United Stales Government nor any agency lhercol, Gility of responsiGovernment. Nees any wattanty, express or implied. or assumes any legal liability or product, or employoes, makes any watrmlecess, or usefu!ness of any information, apparad rights. Refer. bility for the accuracy, completeness, or useft!ness of anfinge privately owned rights. Referproces disclosed, of represents that its use would nocess, or service by trade name, trademark. ence herein to any spesific commercial product, procss, or or imply its endorsement, recommanufactures, or otherwise does not necessarily constitute or unply agency thereof. The views mendation, or favoring by the Uniled States Gorernments ar state or teflect those of the and opinions of authors expressed herein do not

United Staits Government of any agency theraul.
\end{abstract}

TNuclear Engineering Department, Massachusetts Institute of Technology. This work was performed under appointment to the Magnetic Fusion Energy Technology Fellowship progmam which is administered for the U.S. Department of Energy by Dak Ridge Associated Universities.

\section{wothe:

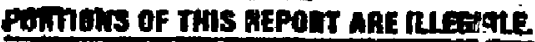 \\ In has wan rewatuced from the bost avallable capy o pormit the brobilest

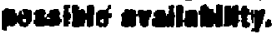


Austract

Integral experiments performed at the Institute for Reactor Development at Julich, West Germany, have raised doubts about the adequacy of current nuclear data and calculational methods in predicting neutron multiplication and leakage from beryllium assamblies bombarded with 14-MeV neutrons. Experimental values of inferred neutron multiplication were reported to be less than calculated values by $225 \%$. We have performed calculations of the experiments using the TART Monte carlo code. The ratio of measured leakage multiplication to our calculated leakage multiplication is 0.85 for 8 -cm-thick beryllium and 0.99 for $12-\mathrm{cm}-$ thick beryllium. However, much uncertainty exists in the procedure leading to the stated experiment values of "apparent multiplication." We also performed calculations for a series of experiments done at LLNL from 1955 to 1956. A 14-MeV neutron source was placed in the center of a cylindricat beryllium assembly $8 \mathrm{in}$. jn radius and $24 \mathrm{in}$. in height. The heryllium assembly was encased in an aluminum can surrounded by a manganese bath. The $r$ atio of experimental to calculated neutron leakage multiplication is 0.88 . Much unceriainty exists in both series of experiments.

\section{Introduction}

Beryllium has been proposed as a material suitable for neutron multiplication in the blankets of fusion reactors. 1,2 The use of beryllium appears attractive from a neutronics standpoint because of its relatively high $(n, 2 n)$ cross section $(20.50 b)$ and relatively low capture cross section (20. ) and threshold energy for $(n, 2 n)$ reactions $(1.7 \mathrm{MeV})$. 
Integral experiments performed at the Institute of Reactor Development at Julich, West Germany, have cast doubt on the adequacy of current nuclear data and calculational methods in predicting neutron mu?tiplication and leakage from beryllium assemslies 8 to $20 \mathrm{~cm}$ thick. ${ }^{3,4}$ A specific concern is the uncertainty of the angular and energy distribution of the secondary neutron in the laboratory system.

This report presents the results of TART Monte Car $10^{5,6}$ calculations of previously reported experimental assemblies. ${ }^{3,4}$ Comparisons are made with previously reported calculated and measured values.

We also present the results of TART Monte Carlo calculations of neutron multiplication in a beryllium cylinder. The neutron multiplication in this assembly was measured as a part of the 8ulk Measurements Project at LLNL. This information has previously been unavailable in the open literature.

Finaliy, we compare the three experiments and discuss uncertainties in the available information relevant to comparisons of calculated to experimental values.

\section{Discussion of German Experiment}

This experiment was first reported at the gth Symposium on Fusion Technology in 1976.3 The experimental assembly is shown in Fig. 1. A central beryllium assemb 1 y $38 \times 38 \times 65 \mathrm{~cm}^{3}$ is surrounded by a polyethylene cube $1.2 \mathrm{~m}$ on a side. The polyethylene was modeled as $\mathrm{CH}_{2}$ with a density of $0.92 \mathrm{~g} / \mathrm{cm}^{3}$. A central channel $14 \times 14 \times 120 \mathrm{~cm}^{3}$ is provided for the beam tube and target assembly of a deuteron accelerator. Thus, the beryllium assembly is a 12 -cm-thick rectangular tube $65 \mathrm{~cm}$ long containing $150 \mathrm{~kg}$ of beryllium metal, which gives a beryllium density of $1.85 \mathrm{~g} / \mathrm{cm}^{3}$. 
The neutron capture measurements used to infer neutron multiplication were done using dysprosium foils as $1 / v$ detectors in the polyethylene assembly with and without the berytlium assembly in place. In the present work, it is assumed, as stated in Fef. 3, that these measuroments are taken at points representative of the entire polyethyiene bulk. No calculated "correction" will be made tn measured data to arrive at a "corrected experimental maltiplication," as was done in Ref. 3. The ability to calculate neutron multiplication in beryllium should be well represented by the calculated ratio of captures in polyethylene with and without beryllium in the assembly. This is lise only measured quantity in this experiment and is represented by the ratio of source-normalized activities in dysprosium foils with and without Deryllium in place.

A comparison of the calculated and measured ratio of polyethylene captures with and without beryllium is shown in Table I. The values shown in parentheses are the TART uncertainties of one standard deviation.

The agreement between experimental and calculated values is considered goud, especially when experimental uncertainties are considered. These experimental uncertainties include the change in neutron energy spectra at the detector locations that would occur when the beryllium mass is removed. This could change the activation of the dysprosium foils because of a change in self-shielding, which was apparently not considered. In addition, inserting the $\mathrm{BF}_{3}$ counter or dysprosiuin foils would cause a localized perturbation in the thermal flux that may not be identical with or without the berylfium mass in place.

The calculations are shown for pure and nuclear-grade beryllium. The inpurity levels used for nuclear-grade berylliun are those for Brush-Wellmarı N-50C specification beryllium which are given in Table A-III. 
Calculated values are also shown with and without corrections for fast captures in carbon. This changes the results hecause the fast captures in carbon increase when the beryllium is removed. Thus, the relative fraction of fast and thermal captures in polyethylene changes and inust be accounted for to correctly represent the $1 / v$ absarptions.

\section{Discussion of Indo-German Experiment}

In a subsequent experiment ${ }^{4}$ conducted under the auspices of the Indo-German Collaboration Program, measurements were made in a similar assembly for beryllium thicknesses of 8,12 , and $20 \mathrm{~cm}$ with the outside dimensions of the polyethylene assembly held constant at $125 \times 120 \times 1206 \mathrm{~m}^{3}$ and source channel dimensions of $125 \times 14 \times 14 \mathrm{~cm}^{3}$.

A detector channel $1.6 \times 1.6 \mathrm{~cm}^{2}$ was constructed in the polyethylene parallel to the axis of the assembly. A l-cm-dianter $\mathrm{BF}_{3}$ counter was moved along the channel and measurentents were made at variaus points. The channe? was then moved by rearranging the polyethylene and the procedure was repeated at several locations in a representative slab of the assembly. Injtial $\mathrm{BF}_{3}$ detector measurements with $12 \mathrm{~cm}$ of beryllium were also done with manganese wires. The agreement between the two techniques was described as good, and a11 subsequent measurements were done with $\mathrm{BF}_{3}$ counters. The comparison technique between manganese wires and $B F_{3}$ counters was not explicitly stated, i.e., profiles were compared along a channel or ratio of counts and activity both with and without beryllium. 
In the analysis of the measured data by Basu et al., 4 calculated corrections were applied to arrive at the "corrected true multiplication." The procegure used in Ref. 4 is out 1 ined as follows:

With no beryllium in: the assembly,

$$
1=A_{0}+L_{0}
$$

with the berylliuin,

$$
M=A_{m}+L_{m}
$$

Where $A$ is the absorption in the polyethyiene, $L$ is the leakage from the polyethylene and $y$ is defined as the true multiplication. The sujscript 0 indicates no beryllium and the subscript $m$ indicates that beryllium is inserted in the assembly. The apparent multiplication is defined as

$$
M_{a}=\frac{A_{m}}{A_{0}}=\frac{\left(M-L_{m}\right)}{\left(1-L_{0}\right)}
$$

Note that $M_{a}$ is the only measured quantity given in Ref. 4 . Thus,

$$
M=M_{a}\left(r-L_{0}\right)+L_{m} .
$$

It is stated in Ref. 4 that the "true multiplication" is calculated from Eq. (4) using values of $L_{0}$ and $L_{m}$ calculated by MORSE. We note that Eq. (4) yields the leakage multiplication rather than true multiplication because of captures in the beryllium mass.

Calculated values of $L_{m}$ and $L_{0}$ from Ref. 4 and TARI are shown in Table II. The leakages from TART are consistently lower than those from Ref. 4, particularly with beryllium in the assembiy. The source of these differences is not known. It is also not known if the Ref. 4 values include jeakage out the source channel. 
Calculated values of beryllium $(n, 2 n)$ reactions and captures $w$ th and without polyethylene surrounding the beryllium are shown in Table Ill. The calculation of $(n, 2 n)$ reactions in beryllium is reasonably consistent between TART and Ref. 4. However, TART predicts up to $50 \%$ more absorptions in beryllium than does Ref. 4. The cause of this discrepancy is not known.

Calculated leakage corrections were made by Basu et al. ${ }^{4}$ to the measured experimentat "apparent muitiplication" to arrive at the "corrected true multiplication." Jt is stated that "the true multiplication was abtained by correctirg for channel leakage, for backscattering of neutrons from polyethylene, and for leakage through the system." ${ }^{4}$ However, only $L_{0}$ and $L_{m}$ were user' to arrive at $M(E q .4)$ from $M_{a}$. The magritude of the backscattering correction was not identified. It was also not specified whether $L_{0}$ and $L_{n}$ contain the leakage out the central channel or if this is a separate calculation.

Using the calculated values of $L_{0}$ and $L_{m}$ from $R e f .4$ and the measured value of $M_{a}$, the corrected true multiplication is obtained as shown in Table 1V. Note that the experimental value of $M$ is slightly different than the value quated in Ref. 4 for ostensibly the same corrections.

We did not consider the data for the $20-\mathrm{cm}$ beryllium thickness because of uncertainties in the geometry. The $20-\mathrm{cm}$ data are noted as $2 \pi$ geometry, but the actual $2 \pi$ configuration, from four possible choices, is not specified. Judging from trends in the data, the $2 \pi$ geometry results were not combined into an equivaient $4 \pi$ geometry. This leaves the 8 - and 12-cm data suitabie for our comparison.

For reasons explained in Section $1 \underline{I}$, the experimental value of $M_{a}$ (the ratio of captures in polyethylene with and without beryllium) is the appropriate value to compare with the calculation. This comparison is given 
in Table $V$ for pure and nuclear grade beryllium. The TART results are virtually identical to the results given in Ref. 4 and are seen to be significantly greater than the experimental value of $M_{a}$. These calculated values are for the entire polyethylene volume.

If the data were integrated on ly over the "representative slab" and not integrated so as to represent the entire polyethylene volume (see further discussion below), the previous comparison would not be appropriate. Instead, the ratio of polyethylene absorptions with and without beryllium should be compared only in the "representative slab" region. This comparison is given in Table VI, which shows much better aqreement between calculated and measured results. The $12-\mathrm{cm}$ data are especially encouraging.

Simplicity is the essence of any experiment aesigned to test the accuracy of ruclear data. As much as possible, the experiment should be a test of nuclear data and not calculational techniques.

The Indo-German experiment has been designed in rectangular geometry. More than 200 measurements were taken for each assembly with the $\mathrm{BF}_{3}$ detector in a representative slab, as shown in fig. 1 . These results were then integrated over all unspecified volume. An incorrect integration technique could give a misleading value of $M_{a}$ even if all the individual measurements were "correct." For an example, the representative slab can be divided into two regions, $A$ and $B$, as shown in Fig. 2 . Note that the relative weighting of Region A values must be greater than that of Region B since the volume represented by Region $A$ in the entire polyethylene volume is 16 times its actual volume and the volume represented by Region $B$ in the entire polyethylene volume is eight times its actual volume. If this relative weighting were not done, the experimental values of $M_{a}$ could be improperiy weighted towards Region $B$ where the different transport path through beryllium 
and polyethylene would affect the flux in this region differet thy than the relatively straight-through penetration into Region $A$. Thus, the integrated results would give an incorrect value of $\mathrm{M}_{\mathrm{a}}$. In addition, th $s$ may not be is truly representative slab because polyethylene captures in regions adjacent to the beam tube are not accounted for.

This effect is seen in the TART calculations, shown in iable J]J. The absorptions in Region B ectually increase when the beryllium is rerioved. Ttis is due to the effects noted at ove.

These concerns ane also related to the variation of the thermal flux within the polyethylene (which the $\mathrm{BF}_{3}$ counter detects) with the fast flux spectrum incident on the poljethylene.

Another interesting comparison is the neutron leakage from the: suriace of the hare beryllium assembly. This is the value calculated as the corrected true multiplication after correcting the appcrent multiplication fur le: 'joo and backscatter from the polyethylene. ${ }^{4}$ The backscatter correction was not given in Ref. 4 . The comparison between the MORSE-derived results and the TART directly caiculated results is shown in Table VIII. These values should be very close in view of ine smai? differences between the calculated values of $M_{a}$ from TART and MORSE. The two sets of values represent the same physical quantity, namely the leakige from the surface of the beryllium assembly per source reutron at thi center of the assembly. The source of this difference is not known.

\section{Bulk Yeasurerients Project Experiment}

In the mid-1950s, a series of experimenis vas performed at LLNL to measure the neutron mu?tiplication of varicis materials in a bulk assembly. 7 
A cylindrical berylliun, assembly 8 in. in radius and 24 in. in height was one of the assemblies used. A $14-\mathrm{MeV}$ neutron source was placer at the center of the assembly and the resultant leakage multiplicatici was measured using manganese bash techniques.

A cylindrical heryllium assembly was constructed using rectangular bars. Penetrations were provided in the beryllium for the accelerator bearn tube and an a courter was used to monitor the target. The source was composed of 14 -riev neutrons produced by $500-\mathrm{keV}$ deuterons incident on the target. The target consisted of A tuncstur disc on which titanium metal was sputcered and tritium was adsorbed inte the titanium.

The entire beryllium and target assembly was placed in a watertight cylindrical aluminutio can with a 30-in. Enside diameter, 30-in. inner height, and $1 / k$-in. wall thickness. The aluminum $c$ an was supported by an adjustable table ir en 8-ft-high cylindrical aluminum tank with a 6,5-ft inner diameter. This tank was then filled to a depth of $6.5-\mathrm{ft}$ with a solution containing $\mathrm{MnSO}_{4}$.

The experimenta procedure was to irradiate the manganese bath with 14-HeV neutruns with or without the berylicum in place. The bath as then stirred to ensure unformity and samples were taken. These samples were then cosunted to determine ${ }^{56}$ Mn activity and were corrected back to the artivity level at the end of irradiation. A correction was then made for relative neutron froduction in the target during the irraricition, and the " $p$ "factor was determined. (The " $\mathrm{p}$ " factor is the ratio of corrected counts to neutrons produced in the target during the bombardment.) The ratio of "p" values with and without the beryllium in place gives the neutron leakage multiplication. 
Several runs were made with and without the beryllium assembly in place for two different baths. The results of these runs were then combined to give a leakage multiplication of $1.93 \pm 0.08$. (The reported uncertainty levels are apparently two stendard deviations, i.e., 95\% confidence level.) An earlier set of data gives a leakage multiplication of $2.10 \pm 0.14$. However, the lower value was believed to be a better value because of better counting geometry, better internal consistency, and a larger number of samples. .

The experimental assentrly was madeled using the TART Monte Carlo code. A solid beryllium cylinder 8 in. in radius and 24 in. in height was placed inside a T/8-in.-thick aluminum can with a 30-in. inside diameter and 30-in. iiside height. A beryllium density of 1.92 was used to match the total beryllium weight of 335 pounds. The nuclear beryllium used in this case was the \$-65 specification as shown in Table A-3. This region was surrounded by a bath region $6.5 \mathrm{ft}$ in diameter and $6.5 \mathrm{ft}$ high. Note that the target assembly and structure in the beryllium assembly and support structure in the tank are not included. In the final model the beam tube and alpha monitor tube were modeled as $0.3-c m-t h i c k$ aluminum tubes $1.25 \mathrm{in}$. in diameter.

Two baths were used. Solution 1 was modeled as water and $16.15 \mathrm{wt} . \% \mathrm{MnSO}_{4}$ with a density of $1.25 \mathrm{~g} / \mathrm{cm}^{3}$. Solution 2 was modeled as water and $18.44 \mathrm{wt}$. $\% \mathrm{MnSO}_{4}$ with density of $1.25 \mathrm{~g} / \mathrm{cm}^{3}$. From the information given, the exact composition of the bath cannot be directly extracted.

The calculated ratio of captures with and without the beryllium in place is shown in Tabie IX. The ratio of experimental to caiculated vaiues for Mn captures is $0.88(0.02 ;$. 


\section{Comparison of Experiments}

An unexplained discrepancy exists between the German and Indo-German experiments. The German experiment reported a value of $\mathrm{M}_{\mathrm{a}}$ for $12-\mathrm{cm}$-thick beryllium of 1.875; the Indo-German experiment reported a value of 1.70 . This difference was never addressed in the Indo-German experiment.

The unceriainty in the experimental results is stated to be $\pm 3 \%$. This seems too small for several reasons: The asseribly must be completely or partially disassembled many times. The reassembly must be done carefully to eliminate voids in the polyethylene. The source normalization would also contribute to the uncertainty.

Bath of these experiments were reported in relatively brief format cone is a summary in the 9th Symposium on Fusion Technology and the other as a Technical Note ${ }^{4}$ in Nuclear Science and Engineering), which makes a rigorous review impossible. The Indo-German Techrical Note is very difficult to interpret. Neither experiment is well-documented to our knowledge.

However, the buik measurements experiment is relatively well-documented in BIR-2 through $B[R-11$, although there is some uncertainty as to the bath composition and structure in the beryllium assembly and tank. In contrast to the experiments using an $1 / v$ detector in polyethylene, the bulk measurements experiment used a bath, which, with thorough mixing, gives a value representative of the entire volume. Thus, the need to numerically reduce many data points to a single value is eliminated.

\section{Conclusions}

Based on our analysis, we have reached the following conclusions: Significant uncertainty exists in the German and Indo-German experiments. 
Specifically, we are concerned about the discrepancy between the 12-cm beryllium data for $M_{a}(i . e ., 1.875$ vs 1.70 ), which was not addressed. In addition, the method of arriving at a single value for $M_{2}$ was not explicitiy stated. It is not clear if $M_{a}$ applies to the representative slab or the entire polyethylene volume. We also noted significant discrepancies between the TART - and MORSE-calculated beryllium absorptions and leakages. If these concerns can be answered, the information from the German and Indo-German experiments should be more useful.

The Bulk Measurement Project's experiment also contains uncertainties, including the bath and beryllium composition. In view of the time that has passed since the experiments were performed, it is unlikely that hese uncertainties can be resolved. Our comparison of our calculations with the experiments is encouraging, and any further resolution of the experimental uncertainty would likely result in better agreement between calculated and experimental values. 
Table I

Comparison of TART Caiculated and Measured Ratio of Captures in Polyethylene (for 12-cm beryllium thickness)

\begin{tabular}{|c|c|c|c|}
\hline & \multicolumn{2}{|c|}{ Ratio of PE captures } & \multirow[b]{2}{*}{ Measured/calcuiated } \\
\hline & Measured $^{a}$ & $\begin{array}{c}\text { TART } \\
\text { calculated }\end{array}$ & \\
\hline \multicolumn{4}{|l|}{ Total PE captures } \\
\hline Pure Be & 1.875 & $2.07(0.05)$ & 0.91 \\
\hline Nuclear-grade Be & 1.875 & $2.01(0.05)$ & 0.93 \\
\hline $\begin{array}{l}\text { Nuclear-grade Be } \\
\text { with Al beam tube }\end{array}$ & $\begin{array}{l}1.875 \\
.\end{array}$ & $1.97(0.02)$ & 0.95 \\
\hline \multicolumn{4}{|c|}{ Fast PE captures subtracted } \\
\hline Pure Be & 1.875 & $2.20(0.05)$ & 0.85 \\
\hline iduclear-grade Be & 1.875 & $2.13(0.05)$ & 0.88 \\
\hline $\begin{array}{l}\text { Nuslear-grade } 3 e \\
\text { with Al beam tube }\end{array}$ & 1.875 & $2.09(0.02)$ & 0.90 \\
\hline
\end{tabular}

afrom Ref. 3. 
Table II

Calculated Neutron Leakage from Experimental Assembly (Per Source Neutron Entering Beryllium)

\begin{tabular}{cccccc}
\hline Thickness, Be or void $(\mathrm{cm})$ & \multicolumn{2}{c}{ MORSE $^{\mathrm{a}}$} & \multicolumn{2}{c}{ TART $^{\mathrm{b}}$} \\
\hline 8 & 0.16 & 0.12 & 0.09 & 0.11 \\
12 & 0.17 & 0.15 & 0.11 & 0.13 \\
20 & 0.22 & 0.22 & 0.12 & 0.20 \\
\hline
\end{tabular}

aThe MORSE results were originally labeled "leakage from polyethylene surface" and presumably include leakage out the central beam port cavity, which is included in the TART values.

DThe TART values have been increased by $3 \%$ to convert to a "per source neutron entering beryllium" basis from a "ver source neutron" basis. TART accuracy to displayed digits. 
Table III

Calculation of Beryllium $(n, 2 n)$ Reactions and

Captures With and Without Polyethylene Surrounding the Assembly

\begin{tabular}{|c|c|c|c|c|c|}
\hline \multirow[b]{2}{*}{$\begin{array}{c}\text { Be } \\
\text { thickness } \\
(\mathrm{cm})\end{array}$} & \multirow[b]{2}{*}{ Polyethylene ${ }^{c}$} & \multicolumn{2}{|c|}{ MORSE ${ }^{a}$} & \multicolumn{2}{|c|}{ TART $^{b}$} \\
\hline & & $\begin{array}{c}\mathrm{Be} \\
(n, 2 n)\end{array}$ & $\begin{array}{c}\text { Be } \\
\text { captures }\end{array}$ & $\begin{array}{c}\mathrm{Be} \\
(n, 2 n)\end{array}$ & $\begin{array}{c}\text { Be } \\
\text { captures }\end{array}$ \\
\hline 8 & No & 0.805 & 0.075 & $0.812(0.005)$ & $0.080(0.001)$ \\
\hline 8 & Yes & 0.880 & 0.105 & $0.828(0.006)$ & $0.121(0.001)$ \\
\hline 12 & No & 1.064 & 0.118 & $1.082(0.009)$ & $0.142(0.002)$ \\
\hline 12 & Yes & 1.113 & 0.170 & $1.096(0.006)$ & $0.276(0.002)$ \\
\hline 20 & No & 1.368 & 0.221 & $1.371(0.009)$ & $0.318(0.003)$ \\
\hline 20 & Yes & 1.381 & 0.299 & $1.388(0.010)$ & $0.445(0.003)$ \\
\hline
\end{tabular}

aFrom Ref. 4.

bFrom Tables A-!V through A-VII, Pure Be.

CThe polyethylene thicknesses quoted in the MURSE results are not consistent with the assembly dimensions. This particular comparison would not be significantly affected by the difference. 
Table IV

Corrected True Experimental Multiplication Using MORSE Calculated Leakagos

\begin{tabular}{cccc} 
Be thickness $(\mathrm{cm})$ & $M_{\mathrm{a}}{ }^{\mathrm{a}}$ & $M^{\mathrm{b}}$ & $M^{\mathrm{a}}$ \\
\hline 8 & 1.33 & 1.33 & 1.35 \\
12 & 1.70 & 1.62 & 1.58 \\
\hline
\end{tabular}

afrom Ref. 4.

bCalculated from data given in Ref. 4 . 
Table $V$

Comparison of TART Calculated and Experimental

Values of Apparent Multiplication in

Entire Polyethylene Volume

Be thickness $(\mathrm{cm}) \quad M_{a}$ (experimental) $M_{a}$ (TART) $\begin{gathered}\text { Experimental/ } \\ \text { TART }\end{gathered}$

Pure Be

$\begin{array}{llll}8 & 1.33 & 1.78(0.03)^{\mathrm{a}} & 0.75 \\ 12 & 1.70 & 2.07(0.05)^{\mathrm{a}} & 0.82\end{array}$

Nuclear-grade Be

$\begin{array}{llll}8 & 1.33 & 1.76(0.03)^{\mathrm{a}} & 0.76 \\ 12 & 1.70 & 2.0 \mathrm{i}(0.05)^{\mathrm{a}} & 0.85\end{array}$

Pure Be

$\begin{array}{rrrr}8 & 1.33 & 3.88(0.03)^{\mathrm{b}} & 0.71 \\ 12 & 1.70 & 2.20(0.05)^{\mathrm{b}} & 0.77\end{array}$

Nuclear-grade Be

$\begin{array}{llll}8 & 1.33 & 1.86(0.03)^{\mathrm{b}} & 0.72 \\ 12 & 1.70 & 2.13(0.05)^{\mathrm{b}} & 0.80\end{array}$

awith total PE captures.

$b_{W i}$ thout fast PE captures. 
Tabie VI

Comparison of TART Calculated and Experimental Values of Apparent Multification in Representative 5lab

\begin{tabular}{lccc} 
Be thickness $(\mathrm{cm})$ & $M_{\mathrm{a}}$ (Experimental) & $M_{\mathrm{a}}$ (TART) & $\begin{array}{c}\text { Experimental/ } \\
\text { TART }\end{array}$ \\
\hline $\begin{array}{l}\text { Pure Be } \\
8\end{array}$ & 1.33 & $1.51(0.04)^{\mathrm{a}}$ & 0.88 \\
12 & 1.70 & $1.71(0.06)^{\mathrm{e}}$ & 0.99 \\
Nuclear Be & 1.33 & $1.49(0.04)^{\mathrm{a}}$ & 0.89 \\
8 & 1.70 & $1.61(0.06)^{\mathrm{a}}$ & 1.06
\end{tabular}

Pure Be

8

i2

Nuclear Be

8

12
1.33

1.70

1.33

1.70 $1.59(0.04)^{b}$

0.84

$1.81(0.36)^{b}$

0.94

awith total PE captures.

bujthout PE captures. 
Table VII

Comparison of Polyethylene Captures in Regions A and B Witha and Without Beryllium

\begin{tabular}{lllll}
\hline & \multicolumn{3}{c}{ Region } \\
\hline Total captures in region & & & \\
With Be & 0.6535 & $(0.0077)$ & $0.1613(0.0032)$ \\
Without Be & $0.2808(0.0041)$ & 0.2249 & $(0.0040)$ \\
Ratio $\left(\frac{\text { with }}{\text { without }}\right)$ & 2.28 & 0.72
\end{tabular}

Fast captures subtracted
With Be
$0.6465(0.0077) \quad 0.1585(0.0032)$
Without Be
$0.2657(0.0041) 0.2127(0.0040)$
Ratio ( with $)$
2.73
0.75

a) 2-cm beryllium thickness. 
Table vIII

Comparison of MORSE-Derived "Corrected True Multiplication" and FART Calculated Leakage from a Bare Beryllium Assembiy

\begin{tabular}{ccc}
\hline Be thickness $(\mathrm{cm})$ & MORSE-derived M & TART leakage M \\
\hline 12 & 1.79 & $1.72(0.02)$ \\
& 2.03 & $1.93(0.01)$ \\
\hline
\end{tabular}


Table IX

Calculated Ratio of Bath Captures with Beryllium to

Bath Captures Without Beryllium

\begin{tabular}{|c|c|c|c|}
\hline & Total captures & $\operatorname{Mn}(n, g)$ & $H(n, g)$ \\
\hline \multicolumn{4}{|c|}{ Solution $1\left(16.15\right.$ wt\% $\left.\mathrm{NinSO}_{4}\right)$} \\
\hline Pure $B e$ & $2.15(0.03)$ & $2.38(0.05)$ & $2.38 \quad(0.05)$ \\
\hline Nuclear $\mathrm{Be}^{\mathrm{a}}$ & $2.04(0.03)$ & $2.25(0.05)$ & $2.25(0.05)$ \\
\hline
\end{tabular}

Solution 2 (18.44 wt\% $\left.\mathrm{MnSO}_{4}\right)$

Nuclear Bea

Nuclear $B e^{b}$ with beam tube

Ratio of experimental to calculated $=\frac{1.93(0.04)}{2.99(0.03)}=0.88(0.02)$

$$
\begin{array}{llll}
2.06(0.04) & 2.28(0.06) & 2.28(0.06) \\
2.00(0.02) & 2.19(0.03) & 2.19(0.03)
\end{array}
$$

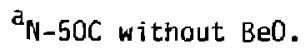

$b_{S-65}$ Be. 
APPENOIX A: SUMMARY OF TART CALCULATIONS

Tables A-I through A-III summarize the TART Monte Carlo models and data used in this report. Tables A-IV through $A-I X$ summarize the calculated values if interest. 
Tabie A-1

Indo-German Experiment TART Mode]

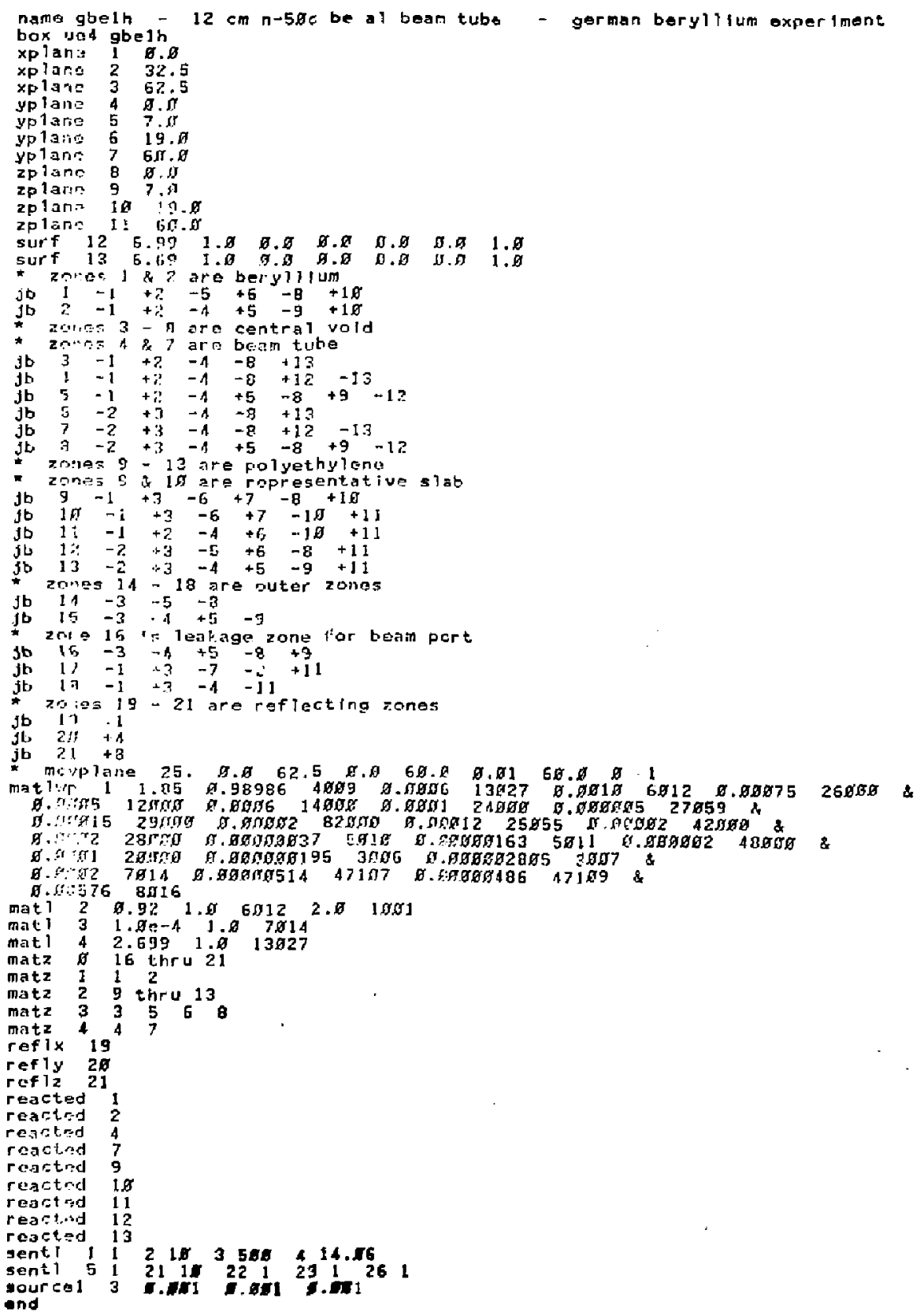


Table A-II

Bulk Measurements Project TART Mode 1

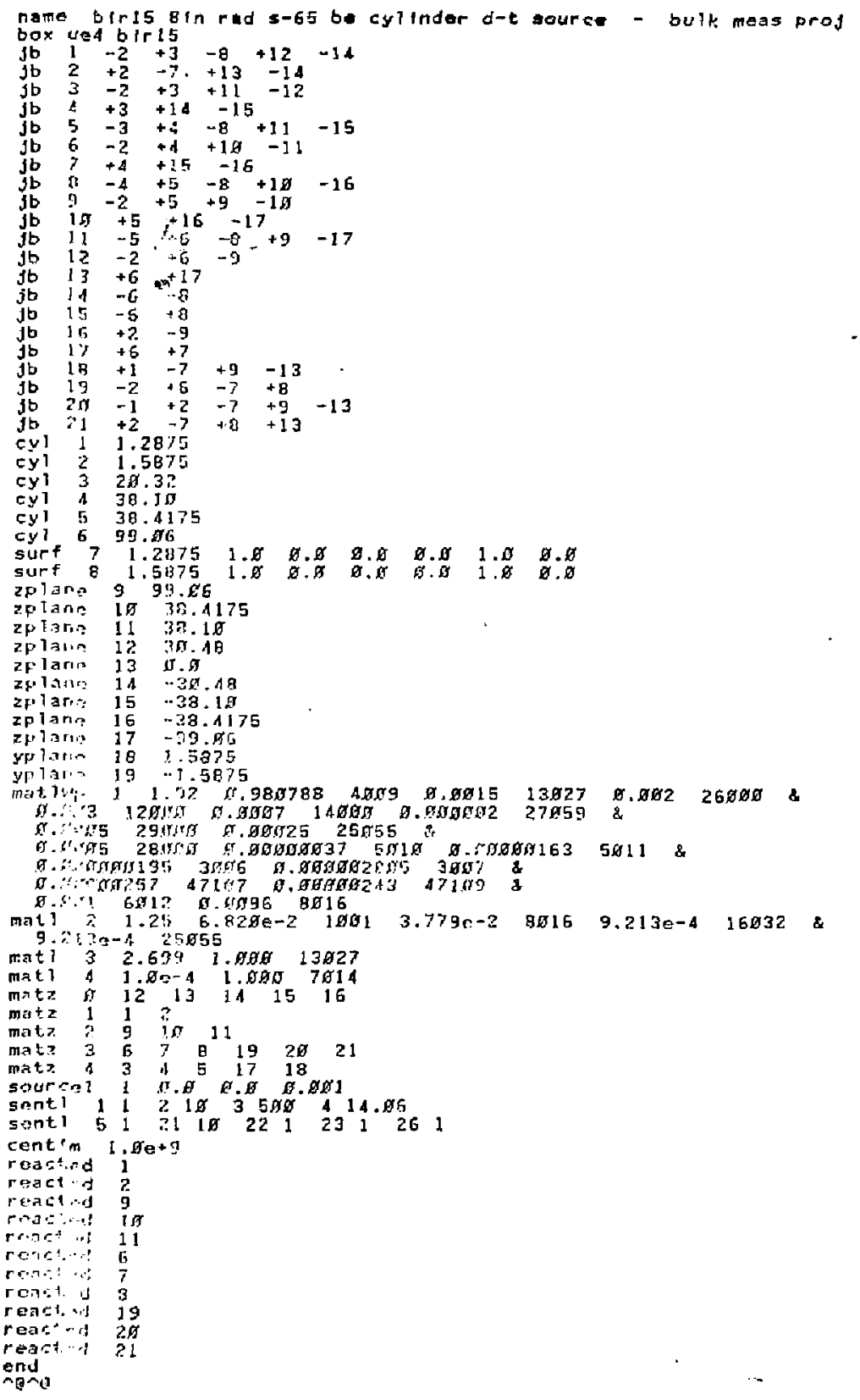


Tabie A-III

Impurities in Nuclear Grade Beryllium

\begin{tabular}{|c|c|c|}
\hline \multirow[b]{2}{*}{ Component } & \multicolumn{2}{|c|}{ Wt $x$} \\
\hline & $N-50 C^{a}$ & $S-65^{b}$ \\
\hline $\mathrm{BeO}$ & 0.9 & 1.5 \\
\hline $\mathrm{Be}_{2} \mathrm{C}$ & - & 0.25 \\
\hline Al & 0.06 & 0.15 \\
\hline C & 0.10 & - \\
\hline $\mathrm{Fe}$ & 0.075 & 0.2 \\
\hline $\mathrm{Mg}$ & 0.05 & 0.3 \\
\hline Si & 0.06 & 0.07 \\
\hline $\mathrm{Cr}$ & 0.01 & - \\
\hline $\mathrm{Co}$ & 0.0005 & 0.0002 \\
\hline $\mathrm{Cu}$ & 0.015 & 0.05 \\
\hline $\mathrm{Pb}$ & 0.002 & - \\
\hline$M n$ & 0.012 & 0.025 \\
\hline Mo & 0.002 & - \\
\hline Ni & 0.02 & 0.05 \\
\hline B & 0.0002 & 0.0002 \\
\hline $\mathrm{Cd}$ & 0.0002 & - \\
\hline Ca & 0.01 & - \\
\hline Li & 0.0003 & 0.0003 \\
\hline $\mathbb{N}$ & 0.02 & - \\
\hline $\mathrm{Ag}$ & 0.001 & 0.0005 \\
\hline $2 n$ & - & 0.015 \\
\hline Be (by difference) & 98.986 & 98.079 \\
\hline
\end{tabular}

${ }^{\mathrm{a}}$ Brush-Wellman Beryllium Specification $\mathrm{N}-50 \mathrm{C}$.

beactor Handbook, Volume 1, Materials, c. D. Tipton, Jr., (Interscience Publishers, New York, 1960). 
Table A-IV

Indo-German Experiment

Bervllium-Polyethylene Assembiy

$12 \mathrm{~cm}$ Reryllium Thickness

\begin{tabular}{|c|c|c|c|c|c|c|}
\hline & Pure Be & Nuclear Be & Nuclear Be & $\begin{array}{l}\text { Nuc Tear Be } \\
\text { W/A? beam tube }\end{array}$ & Void & $\begin{array}{c}\text { Void } \\
\text { W/A1 beam tube }\end{array}$ \\
\hline Total captures in PE & $\begin{array}{l}1.8100 \\
(0.0759)\end{array}$ & $\begin{array}{l}1.7592 \\
(0.0234)\end{array}$ & $\begin{array}{l}1.7559 \\
(0.0748)\end{array}$ & $\begin{array}{l}3.7094 \\
(0.0109)\end{array}$ & $\begin{array}{l}n .8748 \\
(0.0161)\end{array}$ & $\begin{array}{l}0.8697 \\
(0.0072)\end{array}$ \\
\hline Fast cáptures in PF. & $\begin{array}{l}0.0199 \\
(0.0005)\end{array}$ & $\begin{array}{l}0.0200 \\
(0.0005)\end{array}$ & $\begin{array}{l}0.0205 \\
(0.0005)\end{array}$ & $\begin{array}{l}0.0199 \\
(0.0003)\end{array}$ & $\begin{array}{l}0.0619 \\
(0.000 a)\end{array}$ & $\begin{array}{l}0.0597 \\
(0.0004)\end{array}$ \\
\hline $\begin{array}{l}\text { Total captures in } \\
\text { Region } A\end{array}$ & $\begin{array}{l}0.8750^{\mathrm{b}} \\
(0.027 ?)\end{array}$ & $\begin{array}{l}0.8501^{b} \\
(0.0133)\end{array}$ & $\begin{array}{l}0.8267^{b} \\
(0.0181)\end{array}$ & $\begin{array}{l}0.6535 \\
(0.0077)\end{array}$ & $\begin{array}{l}0.5130^{\mathrm{b}} \\
(0.0141)\end{array}$ & $\begin{array}{l}0.2868 \\
(0.0041)\end{array}$ \\
\hline $\begin{array}{l}\text { Fast captures in } \\
\text { Reqion A }\end{array}$ & $\begin{array}{l}0.0009 b \\
(0.0003)\end{array}$ & $\begin{array}{l}0.0100 \mathrm{~b} \\
(0.0003)\end{array}$ & $\begin{array}{l}0.0098^{h} \\
(0.0003)\end{array}$ & $\begin{array}{l}0.0070 \\
(0.000 ?)\end{array}$ & $\begin{array}{l}0.0305 b \\
(0.0008)\end{array}$ & $\begin{array}{l}0.0211 \\
(0.0003)\end{array}$ \\
\hline $\begin{array}{l}\text { Total captures in } \\
\text { Region } 8\end{array}$ & -- & -- & -- & $\begin{array}{l}0.1613 \\
(0.0032)\end{array}$ & -- & $\begin{array}{l}0.2249 \\
(0.0040)\end{array}$ \\
\hline $\begin{array}{l}\text { Fast captures in } \\
\text { Reqion B }\end{array}$ & -- & -- & -- & $\begin{array}{l}0.0028 \\
(0.0001)\end{array}$ & -- & $\begin{array}{l}0.0122 \\
(0.0002)\end{array}$ \\
\hline Captures in beam tube & -- & -- & -- & $\begin{array}{l}0.0225 \\
(0.0002)\end{array}$ & -- & $\begin{array}{l}0.0074 \\
(0.0000)\end{array}$ \\
\hline $\begin{array}{l}\text { Total captures in } \\
\text { Be bulk }\end{array}$ & $\begin{array}{l}0.2155 \\
(0.0 n 22)\end{array}$ & $\begin{array}{l}0.2411 \\
(0.00 ? ?)\end{array}$ & $\begin{array}{l}0.2378 \\
\text { (n.กก?2) }\end{array}$ & $\begin{array}{l}0.2359 \\
(0.0 n 10)\end{array}$ & -- & -- \\
\hline $\operatorname{Be}(n, 2 n)$ & $\begin{array}{l}1.0956 \\
(0.0062)\end{array}$ & $\begin{array}{l}1.0925 \\
(0.0080)\end{array}$ & $\begin{array}{l}1.0785 \\
(0.0066)\end{array}$ & $\begin{array}{l}1.0571 \\
(0.0038)\end{array}$ & -- & -- \\
\hline $\begin{array}{l}\text { Leakage from polyethy- } \\
\text { lene surface }\end{array}$ & $\begin{array}{l}0.0524 \\
(0.0078)\end{array}$ & $\begin{array}{l}0.0538 \\
(0.0037)\end{array}$ & $\begin{array}{l}n .0514 \\
(n .0 n 39)\end{array}$ & $\begin{array}{l}0.0506 \\
(0.0018)\end{array}$ & $\begin{array}{l}0.1178 \\
(0.0047)\end{array}$ & $\begin{array}{l}0.1154 \\
(0.0024)\end{array}$ \\
\hline Leakage from beam port & $\begin{array}{l}0.0546 \\
(0.0032)\end{array}$ & $\begin{array}{l}0.0546 \\
(0.0039)\end{array}$ & $\begin{array}{l}0.05 .30 \\
(0.00 ? 6)\end{array}$ & $\begin{array}{l}0.0471 \\
(0.0014)\end{array}$ & $\begin{array}{l}0.0130 \\
(0.0017)\end{array}$ & $\begin{array}{l}0.0145 \\
(0.0009)\end{array}$ \\
\hline Identifier & GRETAC & GREICB & GRF $1 \mathrm{GA}$ & GBETHC & GBEIIIA & GREIIA \\
\hline
\end{tabular}

a No BeO.

${ }^{\mathrm{h}}$ Total for Reaions A \& $R$. 
Table A-V

Inda-German Experiment

Beryllium-Polyethylene Assembly

$8 \mathrm{~cm}$ Beryllium Thickness

\begin{tabular}{|c|c|c|c|}
\hline & Pure Be & Nuciear Bea & Void \\
\hline Total captures in PE & $\begin{array}{l}1.6017 \\
(0.0220)\end{array}$ & $\begin{array}{l}1.5838 \\
(0.0208)\end{array}$ & $\begin{array}{l}0.8987 \\
(0.0122)\end{array}$ \\
\hline Fast captures in PE & $\begin{array}{l}0.0293 \\
(0.0005)\end{array}$ & $\begin{array}{l}0.0285 \\
(0.0006)\end{array}$ & $\begin{array}{l}0.0620 \\
(0.0009)\end{array}$ \\
\hline Tatal captures in regions $A \& B$ & $\begin{array}{l}0.8576 \\
(0.0158)\end{array}$ & $\begin{array}{l}0.8453 \\
(0.0123)\end{array}$ & $\begin{array}{l}0.5664 \\
(0.0110)\end{array}$ \\
\hline Fast captures in regions $A \& B$ & $\begin{array}{l}0.0167 \\
(0.0004)\end{array}$ & $\begin{array}{l}0.0157 \\
\langle 0.0003\rangle\end{array}$ & $\begin{array}{l}0.0370 \\
(0.0007)\end{array}$ \\
\hline Total captures in Be bulk & $\begin{array}{l}0.1214 \\
(0.0014)\end{array}$ & $\begin{array}{l}0.1357 \\
(0.0016)\end{array}$ & -- \\
\hline $\operatorname{Be}(n, 2 n)$ & $\begin{array}{l}0.8278 \\
(0.0062)\end{array}$ & $\begin{array}{l}0.8179 \\
(0.0077)\end{array}$ & -- \\
\hline Leakage from PE surface & $\begin{array}{l}0.0512 \\
(0.0028)\end{array}$ & $\begin{array}{l}0.0492 \\
(0.0028)\end{array}$ & $\begin{array}{l}0.0920 \\
(0.0043)\end{array}$ \\
\hline Leakage from beam port & $\begin{array}{l}0.0450 \\
(0.0036)\end{array}$ & $\begin{array}{l}0.0416 \\
(0.0029)\end{array}$ & $\begin{array}{l}0.0124 \\
(0.0020)\end{array}$ \\
\hline Identifier & GBE2AA & GBE2CA & GBE2DA \\
\hline
\end{tabular}


Table A-VI

Indo-German Experiment

Beryllium-Polyethylene Assembly

$20 \mathrm{~cm}$ Beryllium Thickness

\begin{tabular}{|c|c|c|c|c|}
\hline & Pure Be & Nuclear $\mathrm{Be}^{\mathrm{a}}$ & Void & \\
\hline Total captures in PE & $\begin{array}{l}1.8760 \\
(0.0253)\end{array}$ & $\begin{array}{l}1.7734 \\
(0.0274)\end{array}$ & $\begin{array}{l}0.8118 \\
(0.0129)\end{array}$ & \\
\hline Fast captures in PE & $\begin{array}{l}0.0107 \\
(0.0005)\end{array}$ & $\begin{array}{l}0.0107 \\
(0.0005)\end{array}$ & $\begin{array}{l}0.0598 \\
(0.0008)\end{array}$ & : \\
\hline Total captures in regions $A \& B$ & $\begin{array}{l}0.6791 \\
(0.0155)\end{array}$ & $\begin{array}{l}0.6790 \\
(0.0168)\end{array}$ & $\begin{array}{l}0.4110 \\
(0.0082)\end{array}$ & . \\
\hline Fast captures in regions $A \& B$ & $\begin{array}{l}0.0040 \\
(0.0003)\end{array}$ & $\begin{array}{l}0.0040 \\
(0.0004)\end{array}$ & $\begin{array}{l}0.0289 \\
(0.0007)\end{array}$ & \\
\hline Total captures in Be bulk & $\begin{array}{l}0.4448 \\
(0.0032)\end{array}$ & $\begin{array}{l}0.4913 \\
(0.0040)\end{array}$ & -- & \\
\hline $\operatorname{Be}(n, 2 n)$ & $\begin{array}{l}1.3882 \\
(0.0095)\end{array}$ & $\begin{array}{l}1.3743 \\
(0.0103)\end{array}$ & -- & \\
\hline Leakage from $P E$ surface & $\begin{array}{l}0.0590 \\
(0.0038)\end{array}$ & $\begin{array}{l}0.0574 \\
(0.0030)\end{array}$ & $\begin{array}{l}0.1828 \\
(0.0054)\end{array}$ & \\
\hline Leakage from beam port & $\begin{array}{l}0.0638 \\
(0.0015)\end{array}$ & $\begin{array}{l}0.0674 \\
(0.0029)\end{array}$ & $\begin{array}{l}0.0126 \\
(0.0016)\end{array}$ & \\
\hline Identifier & GBE3AA & GBE3CA & GBE 3DA & \\
\hline
\end{tabular}

ano BeO. 
Table A-VII

Indo-German Experiment

Bare Beryllium Assembly

\begin{tabular}{|c|c|c|c|c|}
\hline & $\operatorname{Be}(n, 2 n)$ & $\begin{array}{l}\text { Total Captures } \\
\text { in Be Bulk }\end{array}$ & $\begin{array}{l}\text { Total Leakage } \\
\text { from Be Bulk }\end{array}$ & Identifier \\
\hline $8+\mathrm{CmBe}$ & $\therefore$ & & & \\
\hline Pure Be & $\begin{array}{l}0.8116 \\
(0.0053)\end{array}$ & $\begin{array}{l}0.0800 \\
(0.0008)\end{array}$ & $\begin{array}{l}1.7092 \\
(0.0138)\end{array}$ & GBE2EA \\
\hline Nuclear Be & $\begin{array}{l}0.8056 \\
(0.0066)\end{array}$ & $\begin{array}{l}0.0847 \\
(0.0012)\end{array}$ & $\begin{array}{l}1.7214 \\
(0.0174)\end{array}$ & GBE2FA \\
\hline \multicolumn{5}{|l|}{$12-\cos B e$} \\
\hline Pure Be & $\begin{array}{l}1.0877 \\
(0.0077)\end{array}$ & $\begin{array}{l}0.1424 \\
(0.0015)\end{array}$ & $\begin{array}{l}1.9272 \\
(0.0166)\end{array}$ & GBE 1EA \\
\hline Nuciear Be & $\begin{array}{l}1.0707 \\
(0.0042)\end{array}$ & $\begin{array}{l}0.1513 \\
(0.0008)\end{array}$ & $\begin{array}{l}1.9290 \\
(0.0097)\end{array}$ & GBE IFB \\
\hline $20-\mathrm{cm} \mathrm{Be}$ & $\therefore$ & & & \\
\hline Pure Be & $\begin{array}{l}1.3708 \\
(0.0086)\end{array}$ & $\begin{array}{l}0.3177 \\
(0.0034)\end{array}$ & $\begin{array}{l}2.0528 \\
(0.0125)\end{array}$ & GBE3F. \\
\hline Nuclear Be & $\begin{array}{l}1.3876 \\
(0.0071)\end{array}$ & $\begin{array}{l}0.3541 \\
(0.0024)\end{array}$ & $\begin{array}{l}2.0058 \\
(0.0142)\end{array}$ & GBE3FA \\
\hline
\end{tabular}


Table A-VIII

Rulk Measurement's Project.

Bervllium Bulk - Manaanese Rath

\begin{tabular}{|c|c|c|c|c|c|c|c|c|}
\hline \multirow[b]{2}{*}{ Case } & \multicolumn{2}{|c|}{ Be bulk } & \multicolumn{3}{|c|}{ Rath captures } & \multirow[b]{2}{*}{ Remainder } & \multicolumn{2}{|c|}{ Structure captures } \\
\hline & Captures & $(n, 2 n)$ & Totat & H & $M_{n}$ & & Tan & Tubes \\
\hline $\begin{array}{l}\text { Pure Re, solution } 1 \\
\text { (BIR06B) }\end{array}$ & $\begin{array}{l}0.5519 \\
(0.0046)\end{array}$ & $\begin{array}{l}T .1513 \\
(\dot{n} .0087)\end{array}$ & $\begin{array}{l}2.0830 \\
(0.0154)\end{array}$ & $\begin{array}{l}7.47 a n \\
(0.0141)\end{array}$ & $\begin{array}{l}0.6 .322 \\
(0.0063)\end{array}$ & & $\begin{array}{l}0.0473 \\
(0.0009)\end{array}$ & -- \\
\hline $\begin{array}{l}\text { No Be, solution } 1 \\
\text { (BIR07A) }\end{array}$ & -- & -- & $\begin{array}{l}0.0687 \\
(0.0126)\end{array}$ & $\begin{array}{l}0.5934 \\
(0.0115)\end{array}$ & $\begin{array}{l}0.2659 \\
(0.0051)\end{array}$ & & $\begin{array}{l}0.0091 \\
(0.0001)\end{array}$ & -- \\
\hline $\begin{array}{c}\text { Nuclear Rea, } \\
\text { solution } 1 \\
\text { (BIROSA) }\end{array}$ & $\begin{array}{l}0.4025 \\
(0.0028)\end{array}$ & $\begin{array}{l}1.4457 \\
(0.0084)\end{array}$ & $\begin{array}{l}1.9721 \\
(0.022 n)\end{array}$ & $\begin{array}{l}1.3348 \\
(0.0201)\end{array}$ & $\begin{array}{l}0.5981 \\
(0.0090)\end{array}$ & & $\begin{array}{l}0.0387 \\
(0.0006)\end{array}$ & $-\cdots$ \\
\hline $\begin{array}{l}\text { Nuclear Bea } \\
\text { solution? } \\
\text { (BIROQA) } \\
\text { No Be solution } 2 \\
\text { (BIRIOA) }\end{array}$ & $\begin{array}{l}0.4061 \\
(0.0037) \\
\ldots\end{array}$ & $\begin{array}{l}1.4542 \\
(0.0071) \\
--\end{array}$ & $\begin{array}{l}2.0112 \\
(0.019 ?) \\
0.9764 \\
(0.0157)\end{array}$ & $\begin{array}{l}1.2898 \\
(0.0170) \\
0.5658 \\
(0.0139)\end{array}$ & $\begin{array}{l}0.6791 \\
(0.0089) \\
0.2981 \\
(0.2073)\end{array}$ & & $\begin{array}{l}0.0388 \\
(0.0007) \\
0.0090 \\
(0.0002)\end{array}$ & -- \\
\hline $\begin{array}{c}\text { Nuclear Beb } \\
\text { solution ? } \\
\text { (BIRIIA) }\end{array}$ & $\begin{array}{l}0.4097 \\
(0.0029)\end{array}$ & $\begin{array}{l}1.4670 \\
(0.0063)\end{array}$ & $\begin{array}{l}7.0766 \\
(0.0188)\end{array}$ & $\begin{array}{l}1.2681 \\
(0.016 \kappa)\end{array}$ & $\begin{array}{l}0.6675 \\
(0.0088)\end{array}$ & & $\begin{array}{l}0.0387 \\
(0.0007)\end{array}$ & -- \\
\hline $\begin{array}{l}\text { Nuclear } \mathrm{Be} \\
\text { solution } 2 \\
\text { (BIR15C) }\end{array}$ & $\begin{array}{l}0.3580 \\
(0.0015)\end{array}$ & $\begin{array}{l}1.3325 \\
(0.0043)\end{array}$ & $\begin{array}{l}? .9013 \\
(0.008 ?)\end{array}$ & $\begin{array}{l}1.2030 \\
(0.007 .3)\end{array}$ & $\begin{array}{l}0.6544 \\
(0.0038)\end{array}$ & & $\begin{array}{l}0.0354 \\
(0.0002)\end{array}$ & $\begin{array}{l}0.0166 \\
(0.0001)\end{array}$ \\
\hline $\begin{array}{l}\text { No Be, solution ? } \\
\text { (BIR16C) }\end{array}$ & -- & - & $\begin{array}{l}0.0778 \\
(0.0 \cap 67)\end{array}$ & $\begin{array}{l}n .5555 \\
\text { (1). } 0509)\end{array}$ & $\begin{array}{l}0.2084 \\
(0.0031)\end{array}$ & & $\begin{array}{l}0.0088 \\
(0.0001)\end{array}$ & $\begin{array}{l}0.0076 \\
(0.0000)\end{array}$ \\
\hline $\begin{array}{l}\text { Nuclear Ber, } \\
\text { solution }{ }^{\text {d }} \\
\text { (BIR13A) }\end{array}$ & $\begin{array}{l}0 . P 0.37 \\
(0.0019)\end{array}$ & $\begin{array}{l}0.0127 \\
(0.00 n ?)\end{array}$ & $\begin{array}{l}0.7770 \\
(0.0116)\end{array}$ & $\begin{array}{l}n .5023 \\
(0 . n 1 \cap 3)\end{array}$ & $\begin{array}{l}n .75 \Delta 4 \\
(n .005 \Delta)\end{array}$ & & $\begin{array}{l}0.0163 \\
(0.0005)\end{array}$ & -- \\
\hline 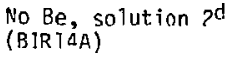 & - & $\ldots$ & $\begin{array}{l}0.9941 \\
(0.0130)\end{array}$ & $\begin{array}{l}0.5418 \\
(0.0175)\end{array}$ & $\begin{array}{l}0.3381 \\
(n .0176 n)\end{array}$ & & $\begin{array}{l}0.0075 \\
(0.0003)\end{array}$ & -- \\
\hline
\end{tabular}

aN-50r Be without BeO.

CS-6.5 Rn.

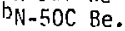

di-n source. Remainder are R-T source. 
Table A-IX

Summary of Fast Captures in Manganese Bath

\begin{tabular}{lll}
\hline & \multicolumn{2}{c}{ Captures } \\
\cline { 2 - 3 } Reaction & With Be & Without Be \\
\hline $0(n, p)$ & $0.0027(0.0001)$ & $0.0202(0.0002)$ \\
$0(n, d)$ & $0.0005(0.0000)$ & $0.0066(0.0001)$ \\
$0(n, \alpha)$ & $0.0128(0.0002)$ & $0.0599(0.0004)$ \\
$S(n, p)$ & $0.0074(0.0000)$ & $0.0057(0.0000)$ \\
$S(n, \alpha)$ & $0.0005(0.0000)$ & $0.0026(0.0000)$ \\
Identifier & $B I R 15 C$ & $B I R 16 C$ \\
\hline
\end{tabular}




\section{References}

1. R. W. Moir, et al, Tandem Mirror Hybrid Reactor Design Study Final

Report, Lawrence Livermore National Laboratory, Livermore, CA, UCID-18808 (1980).

2. J. D. Lee, et al., Feasibility Study of a Fission-Suppressed

Tandem-Mirror Hybrid Reactor, Lawrence Livermore National Laboratory, Livermore, CA, UCID-19327 (1982).

3. P. Fioth, D. Filzer, R. Herzing, N. Kirch, "Neutron Multiplication Effect of CTR Biankets Containing Beryllium," in Proc. 9th Symposium on Fusion Technology (1976).

4. T. K. Basu, V. R. Nargundkar, P. Cloth, D. Filges, S. Taezanowski, "Neutron Nistiplication Studies in Beryllium for Fusion Reactor B Tankets," Nucl. Sci. and Eng., 70, p. 309 (1979).

5. R. F, Plechaty and J, R. Kinlinger, TARTNP: A Couplad Neutron-Photo Monte Carlo Transport Code, Lawrence Livermore National Laboratory, Livermore, CA, UCRL-50400, Vol. 14 (1976).

6. The LLL Evaluated Nuclear natri Library (ENDL), Lawrence Livermore Nationa1 Laboratory, Livermore, CA, LLNL-50400, Vol. 15 (1975).

7. BIR (Bulk Interim Report) 2-11 is a series of reports of manganese bath measurements of neutron multiplication in various materials done at Lawrence Livermore National Laboratory, Livermore, CA, from 1955-1956. 


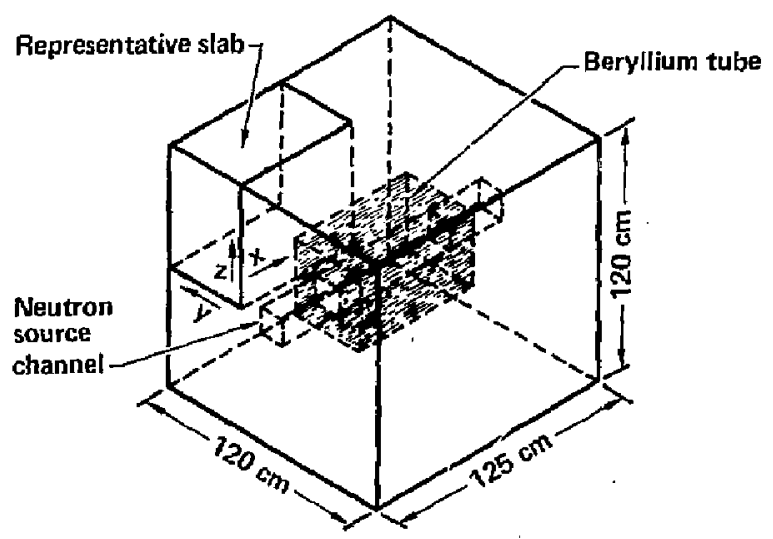

Beryllium-polyethylene system

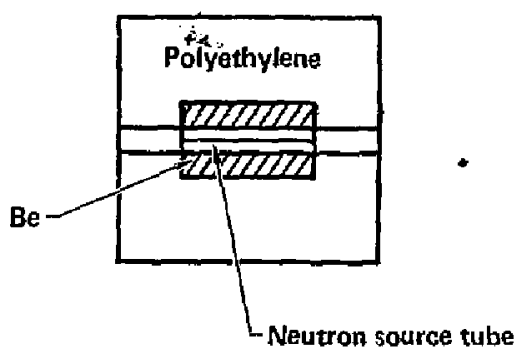

Vertical cross section

Fig. I Schematic diagram of TAR model geametry 


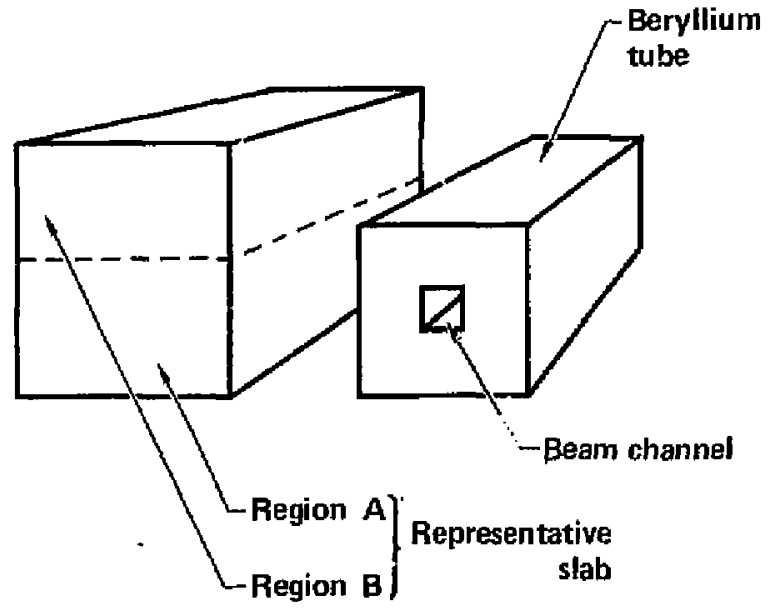

Fig. 2 Schematic of representative slab in entire assembly 